\title{
How to decenter neoliberalism in the analysis of contestation and change? Reflections on the usefulness of Foucault's (extended) governmentality approach
}

\section{Pieter Rondelez ${ }^{1}$ (D)}

Received: 16 May 2020 / Accepted: 13 January 2021 / Published online: 15 February 2021

(c) The Author(s), under exclusive licence to Springer Nature Switzerland AG part of Springer Nature 2021

\begin{abstract}
Neoliberalism has been key term of political and academic debate since the 1990s. Nevertheless, in spite of this centrality, the concept remains vague and highly contested. An influential approach to grasp neoliberalism is the governmentality approach. Nonetheless, academics have pointed to the limitations of using Foucault's oeuvre on governmentality for understanding neoliberalism. In particular, they have urged to develop a more sober assessment of the theoretical possibilities of using Foucault's method and concepts to understand (the hegemony of) globalized neoliberalism. In this article, I argue that Foucault's method on governmentality is far from a limitation in social science. The latter deals with the study of social change. Scholars who want to study social change have to deal with an important epistemological problem: how to study social change without presupposing a certain outcome. Or how to study social change without feeding the hegemonic beast (neoliberalism) you want to slay in the first place? Starting from the argument that we have to go beyond neoliberalism in social theory, this article deals with the question how this could be achieved. I argue that Foucault's (extended) notion of governmentality (taking into account the notion of counter-conduct) is a methodological concretization of the work of Leitner and colleagues who developed a research agenda in order to decenter neoliberalism in the analysis of contestation and change.
\end{abstract}

Keywords Foucault $\cdot$ Decentering neoliberalism - Governmentality $\cdot$ Counterconduct $\cdot$ Social theory $\cdot$ Social change

Pieter Rondelez

pieter.rondelez@ugent.be

1 Department of Conflict and Development, Ghent University, Universiteitsstraat 8, 9000 Gent, Belgium 


\section{Introduction}

Neoliberalism has been described as a controversial, incoherent, and crisis-ridden term (Venugopal 2015). Indeed, there is huge disagreement in the academic world about what neoliberalism actually is and how to conceptualize and study it (England and Ward 2016; Mudge 2008). This vagueness has allowed the concept to expand beyond the contexts to which it originally referred. And this in turn has resulted in ever more different meanings and applications of the concept. ${ }^{1}$ Several scholars have tried to bring order to this debate by categorizing the great variety of interpretations and definitions. ${ }^{2}$ Others went beyond mere cherry-picking between different kinds of definitions and made useful categorizations based on the epistemological dimension (the so-called approaches) ${ }^{3}$ in order to grasp neoliberalism (Cahill and Konings 2017a; O'Neill and Weller 2016). ${ }^{4}$

Since the early 1990s, the notion of governmentality has arguably provided the most influential approach to the study of neoliberalism. Governmentality studies reside in the broader field of post-structuralism which focuses on subjectivities, everyday practices, and discourse (England and Ward 2016; Larner 2000; Mayer and Künkel 2012). ${ }^{5}$ These studies rely on the lecture courses given by Michel Foucault during the 1970s at the Collège de France (Lemke 2001). ${ }^{6}$ However, it is not easy to give a very clear summary or to grasp the essence of all those studies that take neoliberal governmentality as their object of study and critique (Cahill and Konings 2017a). This makes them open to different readings and, ultimately, vulnerable for critique.

Some of the more salient of these critiques were brought together by Zamora and Behrent (2016) in the edited volume Foucault and Neoliberalism. There, several authors point to the inadequacies of Foucault's oeuvre for understanding neoliberalism and warn the reader against trying to develop a theory of neoliberalism based

\footnotetext{
${ }^{1}$ Interesting works that point to this problem—besides the chapter of England and Ward—are: (Clarke 2008; Springer et al. 2016).

2 Important works that make an interesting contribution in this domain are: England and Ward (2016), Ward and England (2007) and Larner (2000).

${ }^{3}$ In many readings, authors detect two important approaches: political economic approaches versus poststructuralist approaches (governmentality studies reside under the latter). For example England and Ward (2016), Larner (2000), Leitner et al. (2007), Mayer and Künkel (2012), and Wacquant (2012)

${ }^{4}$ Some scholars have tried to merge certain approaches. For example, Springer (Springer 2012) tried to combine political economy and poststructuralist approaches by means of conceptualizing neoliberalism as discourse.

5 The latter element of discourse is what distinguishes post-structuralism from the idealist approaches whose scholars are conceiving the (neoliberal) world in terms of ideologies and hegemony. According to Larner (2000), discourse is not understood as a form of hegemonic rhetoric generated and spread by a small elite, but as a system of meaning that constitutes an intelligible connection in and between institutions, practices and identity. Relying on notions such as neoliberal reasons or rationalities, scholars have expressed the idea that neoliberalism and its dominance should not be understood as the top-down imposition of a regime in favor of capital interests, but rather as evolving through a broad field of beliefs, institutions, and practices (Cahill and Konings 2017a).

${ }^{6}$ In particular, the lectures held in 1978 (Security, Territory and Population) and in 1979 (Birth of Biopolitics).
} 
on Foucauldian principles. First, there is the timing of Foucault's lectures at the end of the 1970s, when neoliberalism was still in its proto-stage. Therefore, what Foucault said about neoliberalism is difficult to link to what is nowadays understood by neoliberalism (Behrent 2016). Second, Rehmann, Dean, and Behrent point to the inadequacies of the method of governmentality used by Foucault. Rehmann (2016) asserts that the concept of governmentality has covered a multitude of different meanings and interpretations, and therefore, it is impossible to use it as an analytical concept. Furthermore, Behrent (2016) and Dean (2016) point to Foucault's flaw of implementing the governmentality approach in a very narrow way. Although Foucault claims to study practical dynamics of power, he focuses almost exclusively on texts when trying to grasp neoliberalism. Dean (2016) also points to the tendency to concentrate on neoliberal governmental rationalities rather than on technologies and their modes of implementation nor on the resistances and contestation the latter provokes. The aim of Zamora et al. (2016, p. 183) in this book-besides providing an account of Foucault's political and intellectual positions from the late 1970s onwards - is to develop a more sober assessment of the theoretical possibilities of using Foucault's method and concepts to understand the current global neoliberal regime or as the authors like to call it "the hegemony of globalized neoliberalism".

Besides its conceptual uncertainty and vagueness, the hegemonic character of globalized neoliberalism has been acknowledged by many observers (Cahill and Konings 2017b; Duménil and Lévy 2011; Harvey 2007; Mirowski and Plehwe 2015; Plehwe 2016; Saad-Filho and Johnston 2005). ${ }^{7}$ Whereas some authors interpreted the financial crash in 2008 and its aftermath as a 'hegemonic crisis' or 'turning point' (Mouffe 2018; Mason 2015; Rehmann 2016), ${ }^{8}$ others were mere reluctant in this diagnosis thereby pointing to the flexible capacity of neoliberalism to survive these crises (Cahill and Konings 2017b; Cahill 2014b; Hall 2011; Hendrikse and Sidaway 2010; Kennet and Dukelow 2018). The Crisis Decades of the 1970s never ended which has led to the observation that crisis is a normal permanent condition of neoliberalism (Davidson 2017; Gills 2010; Streeck 2014). Some observers concluded that the hegemony of neoliberalism has been consolidated in the wake of the 2008 financial crisis (Centeno and Cohen 2012; French and Leyshon 2010; Mayer

\footnotetext{
7 Hegemony is here (mostly) understood in a Gramscian way: the supremacy of one class over other classes thereby relying on both consent and coercion (Cahill 2014a); (Hoare and Sperber 2016). Whereas hegemony cannot be deduced from the economic superstructure, neoliberalism's hegemony is found in the construction of its ideas and discourse (Harvey 2007) or ideology (England and Ward (2016)). It is no surprise then that neoliberalism is defined by many academics as a mere class project (Duménil and Lévy 2005). Some authors like Plehwe (2016) warn for a rather simplistic vision on neoliberal hegemony as class hegemony and point to so-called neoliberal hegemonic constellations. Duménil and Lévy (2011) on the other hand detect the strength of the neoliberal hegemony not in its ideology. According to them, neoliberalism should be interpreted as a second financial hegemony.

${ }^{8}$ In the context of the 2008 crisis, although there was no agreement about how to characterize this crisis moment, scholars argued that what we were seeing could be the end of neoliberalism (Mayer and Künkel 2012). When authors talk about neoliberalism's hegemonic crisis, they interpret neoliberalism as the 'latest' or 'last' ideological 'spirit' of capitalism (Eagleton-Pierce 2016). Some observers claimed that those events could be the end of capitalism or the transformation into a post-capitalist order (see for example Mason 2015). In the aftermath of the crisis, academics continued reflecting about the prospects of (neoliberal) capitalism: see for example Streeck (2017) and Wallerstein et al. (2013).
} 
and Künkel 2012; Mirowski 2014a; Oosterlynck and González 2013; Plehwe 2016; Rossi 2017). ${ }^{9}$ This raises serious questions about the possibility of change within and of neoliberal capitalism. It is at this point that academics studying social movements and change are confronted with a great danger: the risk of not only producing and reproducing neoliberalism, but also its hegemonic character (especially the ones who are challenging neoliberalism). Scholars who want to study social change have to deal with an important epistemological problem: how to study social change without creating or feeding the hegemonic beast you want to slay in the first place? ${ }^{10}$

In this article, I counter Zamora's and Behrent's (2016) call for a sober assessment of the theoretical possibilities of Foucault's work in the analysis of the socalled hegemonic neoliberal order. I argue that the strength of Foucault's approach is not situated in the analysis of a particular power regime (and its perceived hegemonic status), but in the study how this power regime is contested and changed. Foucault's oeuvre is indispensable to any intellectual who aims to provide citizens and social movements with the tools to escape that regime and change it. After a short elaboration on the emergence of neoliberalism's perceived hegemony and subsequent calls to go beyond neoliberalism in social theory, I introduce the conceptual move of decentering neoliberalism elaborated by Leitner, Sheppard, Sziarto, and Maringanti in 2007. In the agenda or framework Leitner and others propose, I distill seven broad guidelines or principles. Next, I show how Foucault's work on governmentality - and in particular the combination of his notion of governmentality and counter-conduct (what I define as the extended notion of governmentality) can meet or endorse these seven principles. Using Foucault's (extended) notion of governmentality is a methodological concretization of the work of Leitner and colleagues in order to decenter neoliberalism in the analysis of contestation and change. In the last part, I discuss one limit or restriction of merely assuming the notion of counter-conduct as intrinsically linked to the governmentality approach (in order to decenter neoliberalism) and make some suggestions to go beyond this limit. In the conclusion, I argue why this approach is useful in the context of the uprisings of 2019 and the Covid-19 crisis, and in general, by reflecting on the advantages of the extended notion of governmentality in the study of social change.

\footnotetext{
9 Mayer and Künkel (2012, p. 18) assert that "more evidence is accumulating of an emboldened neoliberal regime rather than of one critically wounded." A similar remark is made by (Rossi 2017, p. 84): "... even after the economic collapse of 2008 and the related legitimacy crisis neoliberalism has firmly retained its power as todays hegemonic governmental rationality."

10 The notion of 'the hegemonic beast' is based upon the work of Gibson-Graham (2006, p. 1) who in the book The End of Capitalism argues that although we want to understand the (capitalist) world in order to change it, the "project of understanding the beast has itself produced a beast". In other words, the way we understand capitalism seems to have contributed to a crisis in left politics.
} 


\section{Feeding the hegemonic beast}

Although neoliberalism's origins is situated in the interbellum (Mirowski and Plehwe 2015; Senellart et al. 2008; Slobodian 2018), the end of the Cold War could be considered as the ultimate victory that enabled neoliberalism to consolidate itself as a hegemonic framework (or, more correctly, as a framework that has been interpreted as hegemonic by friend and foe). The fall of the Berlin Wall was also the moment when Fukuyama (1989) concluded that history in its totality had come to an end. However, this was not the first time that someone came to this conclusion. According to Hegel this already was the case in 1806 when Napoleon defeated the Prussian monarchy at the Battle of Jena. Both Fukuyama and Hegel saw in the events of their time history coming to an end for exactly the same reason. Both were convinced that history would ultimately culminate in an absolute moment in which a final rational form of society and state would come into being. Fukuyama interpreted an event - the end of the Cold War-as the end point of man's ideological evolution and the universalization of Western liberal democracy and free-market capitalism. His claim that history had ended can be explained by his conviction that he had found in history the ultimate motor or force (Coolsaet et al. 2006). The immediate consequence of the belief of having detected an irresistible force in history is that the latter has to be ended because its explanatory force is made visible. According to Fukuyama, there was presumably no more history that could supply alternative pathways for societies other than catching up with Western modernity (Burchardt and Kirn 2017; Fukuyama 1989).

Burchardt and Kirn (2017) assert that the end of the Cold War resulted in a major reshaping of social theory and the conceptual vocabularies social scientists use to interpret the world. They argue that in mainstream social theory and research, the end of the Cold War culminated in two interrelated notions. First - and in line with Fukuyama's argument — there was the triumphant return of positivist modernization theories residing under the banner of globalization. These theories are characterized by (the assumption of) a linear progression of history toward a standard mode of society operationalized and made visible by core institutions such as the market economy, parliamentary democracy and the rule of law. The transition toward liberal democracy and free-market economies were seen as the endpoint or horizon of history: there was no alternative. Second, Burchardt and Kirn (2017) claim that the changes and variations in capitalism's organization after 1989 have shaped the directions and paradigms of social sciences which have converged around new narratives and theories of neoliberal capitalism. In particular, neoliberalism was transmuted in an unquestionable framework in which both proponents and critics became immersed. This is exemplified by the fact that Margaret Thatcher's 'There is no alternative' corresponds with the left-wing critique, which posits that neoliberalism is best understood as an economic pensée unique (Plewhe 2015).

Purcell (2016) argues that this is the moment when a significant group of social scientists started to suffer from a serious illness: an obsession with neoliberalism. 
Whereas neoliberalism had largely disappeared from the radar by the 1960s-the moment when many thinkers in the neoliberal thought collective stopped referring to themselves as neoliberals (Mirowski 2014b) - from the 1990s onwards the notion of neoliberalism re-entered as a key concept in many political and academic debates (Thorsen 2010). In fact, the concept was revitalized by opponents of liberal reforms who used the concept as a tool of political rhetoric, mostly unaware of its original meaning (Hartwich 2009). Springer et al. (2016) argue that it was the moment when neoliberalism became a means of identifying a seemingly ubiquitous and omnipotent set of market-oriented policies which led to a wide range of social, political, ecological, and economic problems. Neoliberalism became a swearword for the left, a synonym for everything they despised and, in many instances, did not comprehend (Hartwich 2009). ${ }^{11}$ Jessop (2013) asserts that neoliberalism provides a socially constructed term of struggle that frames criticism and resistance. Accordingly, questions should be raised as to whether it provides a rigorously defined concept that can guide research in social sciences or it is more of an obstacle (O'Neill and Weller 2016). ${ }^{12}$ Some even have argued to get rid of the concept altogether (Barnett 2005; Venugopal 2015).

Purcell's argument follows Nietzsche's account of resentment, a term introduced in the Genealogy of Morals (Nietzsche 1878a, b). According to Purcell (2016), Nietzsche's concept of resentment arises when those in society who are oppressed become consumed by thoughts of their oppressors. This is part of what Nietzsche (1978b, pp. 29-32) frames as the revolt of slaves in the realm of morality. The latter starts the moment that resentment becomes procreative and produces values. The actions of the oppressor are defined as evil and, consequently, the good is interpreted as its opposite, or whatever is not evil. Resentment is a destructive energy since the only action it can think of is to resist what is evil (Purcell 2016). Applied to the debate on neoliberalism Purcell (2016, p. 613) argues that:

As theorists we can only sing in the key of critique. We meticulously record and discuss the crimes and contradictions of neoliberalism. When we imagine the world we want instead, we can only speak in terms of not-neoliberalism, of cancelling out the current political-economic regime. When we act, we can only act in the register of protest, resistance, contestation, and refusal - of struggle against neoliberalism. We turn our faces and our bodies toward neoliberalism, it occupies the entirety of our vision and our imagination, we bath in its dark light, and we can think only of blocking it, disrupting it, and, one day, in our fondest dreams, causing it to collapse

\footnotetext{
${ }^{11}$ See also Venugopal's work (Venugopal 2015). Venugopal $(2015,179)$ asserts that "neoliberalism is defined, conceptualized and deployed exclusively by those who stand in evident opposition to it, such that the act of using the word has the twofold effect of identifying oneself as non-neoliberal, and of passing negative moral judgment over it." At the conclusion Venugopal (2015, p. 183) argues that "neoliberalism serves as a rhetorical tool and moral device for critical social scientists outside of economics to conceive of academic economics and a range of economic phenomena that are otherwise beyond their cognitive horizons and which they cannot otherwise grasp or evaluate".

${ }^{12}$ An interesting discussion was organized in 2012 dealing with the question 'has the concept of neoliberalism become an obstacle?' in the domain of anthropology. This debate was edited for publication by Soumhya Venkatesan (Eriksen et al. 2015).
} 
Resentment is not only a destructive energy; it is also counterproductive (Purcell 2016). It is a destructive force since every attempt, strategy, tactic, and idea is focused on the eradication of what is evil without any independent idea of what is supposed to be good. Even if the objective of the destruction of evil succeeds, nothing could be offered in place of the old society since the agent of resentment lacks a positive idea of the good. Nonetheless, this destructive objective is unlikely to be achieved for two related reasons. First, the agent of resentment will never succeed in his/her mission to seize power from his oppressor since by understanding their oppressor they fail to examine themselves. The obsession by the agent of resentment of its oppressor leads him or her ultimately to the point where he/she is no longer able to change the condition(s) of his/her oppression. The reason for one's inability to escape the cage, is that they have started to build or refine the cage themselves. Second, this is the logical outcome of their production of the value of good as a mere derivative of what is evil. For the good to be real, evil cannot be eradicated. The agent of resentment not only co-creates the cage, but also likes to be in the cage because it gives meaning to their lack of power and legitimates the battle they are conducting but from which they know they cannot win.

The illness Purcell (2016) is referring to is particularly prevalent in the population of critical social scientists who have developed critiques in order to end or go beyond the current neoliberal regime. Social sciences are not only a matter of analyzing the world, but also making it change for the better (Pinson and Morel Journel 2016). Whereas social science has been linked to the idea of normality of change (since the end of the eighteenth century), the relationship between social science and change has been characterized from the very start with a gravitational force: conservatism (Wallerstein 2004). ${ }^{13}$ The notion of critique could be seen as the logical reaction to this tendency of preserving the status quo. Critical scientists ranging from Marx to the members of the Frankfurter School have recovered the notion of theory to make it useful in and for movements with the aim to question the status quo (and its truth-power effects) and to bring radical and liberatory social change (Calhoun and Karaganis 2001). Even more, critical theorists or scientists are engaged in the struggle and try to contribute in changing the current order into a better (more just, more equal, ...) place. ${ }^{14}$

\footnotetext{
13 The translation of this force in science is known by the name 'positivism'. Positive science assumes that there is an external world understood as an objective reality that is just waiting out there for being discovered by the observer. This world is external to the observer and can be construed as separate from those who study it (Burawoy 1998). Nevertheless, as Burawoy rightly observes, positivism was at once science and ideology. This leads us to Comte whose ambition was to replace metaphysics with positivism: no longer would man the observer busy himself with abstract notions, but only with empirically detecting and categorizing facts in order to discover laws or truth (Burawoy 1998; Doom 2006). However, taking notice that women are not equal to men or that blue collar workers are subaltern to entrepreneurs is a neutral observation that could lead us to two pathways: either you accept that what you have observed has to be changed; or you accept the existing order as something that has to be defended. Comte opted for the latter in order to preserve order and as a consequence his attempt to go beyond metaphysics turned him into a mere conservative who transformed ideology into science.

14 It reminds us what Horkheimer (Horkheimer 1972, pp. 245-246) said about critical theory: "To that extent the critical theory is the heir not only of German idealism but of philosophy as such. It is not just a research hypothesis which shows its value in the ongoing business of men; it is an essential element in
} 
But how does this illness of resentment manifest itself in the population of critical social scientists? According to Calhoun and Karaganis (2001), critique (in the tradition of critical theory) refers not to criticism in the common negative sense of the term, but to a process of examining and understanding the conditions and power structures that shape our current social reality (Calhoun and Karaganis 2001). They point to four dimensions that are crucial for this project. For now, it is enough to focus on the first two dimensions. First, critical theory starts from the idea that the conditions of knowledge are not self-evident. A world external to the observer is rejected and refers to the positionality of the researcher that does not detect a world but produces one. Therefore, critical analysis reveals that social reality is not simply a matter of surface appearances, but is a product of underlying causes and conditions that cannot be properly understood by mere empirical generalization. ${ }^{15}$ Theories are required to explain and understand the world under investigation. In order to comprehend data, we rely on concepts and theories and because of this use of what could be seen as conceptual lenses, social scientists will produce a world while trying to comprehend it at the same time (Bogaert 2011; Burawoy 2009; Calhoun and Karaganis 2001). Positivists would interpret this as the biggest tragedy of social sciences. For scholars relying on a reflexive or interpretative approach, this is precisely what social sciences is all about. Nevertheless, a great danger looms in social science: the danger of turning the critical social scientist into an unconscious conservative.

This remark is particularly relevant regarding the observation that neoliberal hegemony survived its first global crisis in 2008, which raises serious questions about the possibility of change within and of neoliberal capitalism (Mayer and Künkel 2012). It is at this point that academics studying social movements and change are confronted with a great danger: the risk of not only producing and reproducing neoliberalism, but also its hegemonic character (especially the ones who are challenging neoliberalism). Sites (2007) asserts that how one conceptualizes the fundamental operations of early twenty-first century capitalism and neoliberalism may have important implications for the analytical valence of oppositional challenges. If you define neoliberalism as a highly stable and resilient form of capitalist regulation (for example (Peck and Tickell 2002), ${ }^{16}$ you have to be aware of the danger that this abstract theoretical lens conceptualizes the reciprocal interaction between

\footnotetext{
Footnote 14 (continued)

the historical effort to create a world which satisfies the needs and powers of men ... the theory never aims simply at an increase of knowledge as such. Its goal is man's emancipation from slavery".

15 The other two dimensions mentioned by Calhoun and Karaganis (2001, pp. 180-181) are: "Thirdly, critical theory seeks to analyze social theory itself in terms of the basic categories of understanding different theories employ ... Fourthly, critical theory is shaped by a critical engagement with society."

16 In the conclusion of their article, Peck and Tickell (2002, pp. 401-401) argue that "one of the most striking features of the recent history of neoliberalism is its quite remarkable transformative capacity. To a greater extent than many would have predicted, including ourselves, neoliberalism has demonstrated an ability to absorb or displace crisis tendencies, to ride - and capitalize upon-the very economic cycles and localized policy failures that it was complicit in creating, and to erode the foundations upon which generalized or extra-local resistance might be constructed. The transformative potential-and consequent political durability - of neoliberalism has been repeatedly underestimated, and reports of its death correspondingly exaggerated."
} 
neoliberalism and contestation as asymmetrically favoring the former (Leitner et al. 2007). From an academic viewpoint the way social change is analyzed depends on how neoliberal capitalism is theorized. The latter exerts a gravitational pull or a mesmerizing effect which can create blind spots in our way of looking at the world.

This is eloquently shown by Pinson and Morel Journel (2016) who developed a categorization of limits of what they call the neoliberalization thesis. ${ }^{17}$ Besides definitional, descriptive and analytical limits they also point to so-called normative limits. The latter are shortcomings of using the notion of (urban) neoliberalism in combination with the normative stance of academics who see social sciences as a militant's tool (the so-called radical critical thinkers). First, they assert that practical alternatives to the current conventional wisdom that is supposed to dominate (urban) policy-making are rarely addressed in the neoliberalization literature. According to them by neglecting the description of ideological and practical alternatives, defenders of the neoliberalization thesis have not only weakened its overall explanatory system, but they have also indirectly contributed to inhibiting the emergence of alternatives (Pinson and Morel Journel 2016, p. 148):

By reifying neoliberalization as the sole hegemonic project able to change the world, the scholars defending the neoliberalization thesis have unwittingly deprived alternative forces for change of any form of social visibility.

Also, they claim that such a stance has not been very helpful in providing progressive forces a grip on reality and an assertive view of their ability to change it (Pinson and Morel Journel 2016, p. 148):

If the social sciences are not only a matter of analysing the world but also of making it change for the better, it is the duty of social scientists to detect seeds of progressive change.

Scholars who reduce all the transformation in (urban) society to a neoliberal force or reality, have deprived not only themselves but also progressive movements of a more complete vision of ongoing change and its concrete mechanisms and processes (Pinson and Morel Journel 2016). Therefore, Purcell (2016) argues that what we need is a completely different way to think about and be in our world, in order to train ourselves not in terms of negating what exists. He refers to already existing frameworks such as Deleuze and Guattari's collaborative work that teach us to focus our attention on our power to produce and create the world. But whereas Deleuze and Guattari do not argue that we should entirely neglect apparatuses of capital and the state-which indeed have a controlling function on our power to produce-Purcell seems to argue that there is little point in resisting neoliberalism or protesting austerity to take a more radical stance. He simply argues that we completely need to stop talking about neoliberalism and that we need to become obsessed with ourselves and the other forms of life that we are already capable of creating. Burchardt

\footnotetext{
17 Their categorization of limits on the theory of urban neoliberalization is also useful in order to contemplate on the usefulness of the concept 'neoliberalism' and 'neoliberalization' as a whole (in particular concerning what they call 'normative limits').
} 
and Kirn (2017) take a more nuanced stance by arguing that there is a need to move social theory beyond the analytic of neoliberalism. ${ }^{18}$ The contributions by Purcell, Burchardt and Kirn, Pinson and Morel Journel provide interesting entrypoints in order to conduct research without the risk of (re)producing neoliberalism's hegemonic status or without feeding a hegemonic beast you pretend to slay in the first place. Nevertheless, questions remain about what methods or instruments could be used in order to succeed in this endeavor. Whereas the stance of Purcell to simply neglect neoliberalism is a step too far, the question remains what it means to move beyond neoliberalism in social theory (without jettisoning every theory or thought on neoliberalism to the dustbin). How could this be achieved practically and for what specific aims?

\section{Going beyond neoliberalism in social theory: decentering neoliberalism}

\section{Seven principles of decentering}

Scholars who want to study social change thus have to deal with an important epistemological problem: how to study social change without creating or feeding the hegemonic beast you want to slay in the first place? Already in 2007, Leitner et al. (2007) dealt with this issue by arguing that it is necessary to decenter neoliberalism in critical analysis. This conceptual move of decentering neoliberalism is part of a broader research agenda developed in their book 'Contesting Neoliberalism, Urban Frontiers' for studying how neoliberalism articulates with its contestations (in and beyond cities) in a way that does not presuppose a certain outcome.

The agenda or framework Leitner et al. (2007) propose, consists of broad guidelines or principles. The concrete entrypoint is the remark that in the literature, there is a focus on neoliberalization as a top-down process that can inadvertently reinforce its hegemonic status. ${ }^{19}$ While it is necessary to theorize neoliberalism in order to understand specific cases, Leitner and her colleagues are concerned that keeping neoliberalism at the center of critical analysis can reify its ubiquity and power, even when the intent is critique. The reason they give is that because of this stance, insufficient attention is paid to the multiple and complex contestations that may reify, but also rework and seek to supplant neoliberalism. This is in line with the critique developed by Pinson and Morel Journel (2016). Leitner et al. (2007) assert that research on neoliberalism and contestation usually begins with neoliberalism, thereby regarding contestations as secondary and reactive (which reminds us to the critique developed by Purcell).

\footnotetext{
18 I want to emphasize that to develop a more nuanced stance means going beyond neoliberalism without jettisoning every theory or thought on neoliberalism to the dustbin.

19 While acknowledging that many studies have focused on the top-down impacts of neoliberalism on urban livelihoods, the argument that much less attention has been paid to bottom-up contestation of this agenda within and beyond individual cities is according to me no longer valid at the time of writing.
} 
Leitner et al. (2007) argue that this move of taking the internal logic of neoliberalism as a starting point risks essentializing it. In order to prevent this, they seek to decenter neoliberalism's theoretical status (among both proponents and critics). In their work I detected the following principles or guidelines that can serve as a guide that could be used in order to decenter neoliberalism in the analysis (Leitner et al. 2007):

- Principle 1: Close empirically grounded analysis is essential to better understand neoliberalism and to imagine and create alternative (urban) futures.

- Principle 2: Be aware of and elaborate on neoliberalism's own beginnings as a project of contestation embedded in alternative political and economic projects and imaginaries.

- Principle 3: Conceptualize contestation as more than just resistance to neoliberalism.

- Principle 4: Conceptualize contestation and neoliberalism as co-implicated.

- Principle 5: Focus on a wide range of robust alternative imaginaries and practices.

- Principle 6: Conceptualize contestation as exceeding neoliberalism.

- Principle 7: Do not start with neoliberalism as such, but at points where it is articulated with and through moments of contestation.

Of course, being aware of these seven principles is one thing. Turning it into practice is something entirely different. It is exactly here where Foucault's work becomes very useful. The following sections deal with the question how the work of Foucault-in particular the combination of his notion of governmentality and counter-conduct (what I define as the extended notion of governmentality) — can meet with or endorse the seven principles outlined above.

\section{The usefulness of Foucault's notion of governmentality}

According to Dean (2010a), the notion of governmentality needs to be understood in the context of Foucault's thought itself, and therefore, you have to be careful in allowing the term to transform into a kind of dogma or to become a mere social science methodology. Governmentality is first and foremost a historical phenomenon. Foucault introduced his concept of governmentality in his lecture series in 1977-1978 'Territory, Security and Population' in which he conceptualizes the notion as a specific historical phenomenon or regime of power (Senellart et al. 2007). Governmentality is the name for the regime of power deployed in the eighteenth century which had "the population as its target, political economy as its major form of knowledge and apparatuses of security as its essential technical instrument" (Foucault 2007b; Senellart 2007). The introduction of this concept should be understood in the context of Foucault's intellectual journey of understanding power beyond the notion of the law (Davidson 2003). In 'The Will To Knowledge', Foucault (1976, pp. 139-145) asserted that "in thought and political analysis we have still not cut off the head of the king." In his examination of how power evolved through time, he 
observed two other forms of power: (1) disciplinary power which developed in the seventeenth and eighteenth century; (2) biopolitics, which emerged in the second half of the eighteenth century, and that was not focused on the individual but on the population as a whole. These two powers should be considered as two parts of the same coin called biopower defined as power over life or the power that replaced "the ancient right to take life or let live by a power to foster life or disallow it to the point of death" (Foucault 1976, p. 138). Foucault (2003) linked the instruments of biopolitics to the notion of security. ${ }^{20}$ In his lecture series of 'Territory, Security and Population' in 1977-1978, he wanted to elaborate further on these security mechanisms, but this led him more to focus on the concept of government, and ultimately, he introduced the notion of governmentality (Senellart 2007). Foucault seemed to use the notion of governmentality as a synonym of biopolitics (and in particular how the latter evolved and came into being from the end of the eighteenth century onwards) (Foucault 2007b; Senellart 2007).

However, Foucault went beyond this specific historical meaning of governmentality. This shift occurs almost immediately or simultaneously because he focused on the history of governmentality itself. What he tried to do was to establish a genealogy for biopower and for this reason-according to Fontana and Bertani (2003)he developed and used the notion of governmentality. It is impossible to detach the notion of governmentality from genealogy, both in its historical version and more abstract meaning. With the latter I mean that the notion of governmentality shifted to a more general and abstract meaning (Senellart 2007). According to Senellart, from 1979 onwards, the concept no longer (only) referred to the governmental practices of a particular regime of power such as Raison d'État or liberalism.

Because of its link with genealogy and its evolution as a concept to a more abstract meaning, I reject the abovementioned claim by Dean. Instead, I argue that governmentality is useful both as a concept and as a method in the aim to decenter neoliberalism in scientific analysis. By using this concept, one (pre-)condition and two principles to decenter neoliberalism are implied. First, making use of the notion of governmentality for understanding neoliberalism prevents you from seeing neoliberalism as a top-down process. Governmentality, in its abstract meaning, consists of the practice of governing (Gordon 1991). Government is defined as the conduct of conduct in both a wide and narrow sense. On the one hand, the notion of government referred to different ways of directing the conduct of individuals and groups: the government of children, souls, communities, families, the sick (Foucault 1994c). On the other hand, governmental practices are understood as political government in the strict sense. In the lecture series of 1978/1979, Foucault focused in particular on governmental practices as political government (Foucault 2008a; Gordon 1991). However, from 1979 onwards, Foucault no longer uses this notion to grasp a particular (political) regime of power but as an analytical tool for studying power relations

\footnotetext{
${ }^{20}$ On 17 March 1976 (in the lecture series of Society must be Defended) Foucault (2003, p. 246) argues that: "In a word, security mechanisms have to be installed around the random element inherent in a population of living beings so as to optimize a state of life. Like disciplinary mechanisms, these mechanisms are designed to maximize and extract forces, but they work in very different ways."
} 
in general (Senellart 2007). According to Foucault (1994c), the term conduct or the "conduct of conduct" is very useful in understanding the specificity of power relations.

What makes power relationships so specific? The key characteristic of power relations entails the existence of possibilities, the recalcitrance of the will or more general: freedom (Foucault 1994c). In the 'Subject and Power', Foucault (1994c, pp. 138-139) asserts that:

When one defines the exercise of power as a mode of action upon the actions of others, when one characterizes these actions as the government of men by other men - in the broadest sense of the term - one includes an important element: freedom. Power is exercised only over free subjects, and only insofar as they are "free". By this we mean individual or collective subjects who are faced with a field of possibilities in which several kinds of conduct, several ways of reacting and modes of behaviour are available. Where the determining factors are exhaustive, there is no relationship of power: slavery is not a power relationship when a man is in chains, only when he has some possible mobility, even a chance of escape. (In this case it is a question of a physical relationship of constraint.) Consequently, there is not a face-to-face confrontation of power and freedom as mutually exclusive facts (freedom disappearing everywhere power is exercised) but a much more complicated interplay

This complex interplay between power and freedom entails the notion of the subject that is not only recognized as the other (or the one over whom power is exercised) but also as "a subject who acts" or at least has the possibility to act (Foucault 1994c, p. 138). Power relationships are not a one-way direction but are embedded in a field of possibilities in which subjects can exhibit various forms of responses and actions. According to Foucault (1994b, c) governing has always been "a versatile equilibrium" in which there is a conflictual and complementary relationship between techniques or technologies of power ${ }^{21}$ (that determine the conduct of subjects or

\footnotetext{
${ }^{21}$ I explicitly use the notion of technologies of power instead of technologies of domination for the following reasons. Foucault sometimes defines this technology of power also as technology of domination, although he clearly makes a difference between the two (Foucault 1994b, pp. 147-148). First, he argues that all four types of technologies are associated with a certain type of domination. Second, in his definition of technologies of power, he explicitly asserts that these technologies of power can submit the conduct of individuals to "certain ends of domination" (Foucault 1994b, p. 146). Rehmann (2016) argues that Foucault did not apply this distinction between domination and power in a consistent fashion. The notion of domination is also to a certain extent in contradiction to the notion of freedom which is an important (pre-)condition for the exercise of power. According to Lemke (Lemke 2000, 4-5), Foucault identified domination as "a particular type of power relationship that is both stable and hierarchical, fixed and difficult to reverse. Domination refers to those asymmetrical relationships of power in which the subordinated persons have little room for maneuvre because their margin of liberty is extremely limited." In an interview in 1984, Foucault (1994a, pp. 40-41) clarified the relationship between power and domination by making a distinction between three levels in his analysis of power: strategic relations (between liberties), techniques of government and states of domination: "It seems to me that we must distinguish between power relations understood as strategic games between liberties-in which some try to control the conduct of others, who in turn try to avoid allowing their conduct to be controlled or try to control the conduct of the others - and the states of domination that people ordinarily call "power". And between the two, between games of power and states of domination, you have technologies of governmentunderstood of course, in a very broad sense that includes not only the way institutions are governed but
} 
the conduct of others) and techniques or technologies of the self (that permit subjects-in particularly individuals- to self-conduct or to construct and modify the self: body, mind, soul). In other words, government as the conduct of conduct ranges from governing others to governing the self (Lemke 2001). In Technologies of the Self, Foucault (1994b) defines this encounter between these two forms of technologies as governmentality.

Instead of speaking in terms of government, Foucault used the notion of governmentality (or rationality of government) which he equated with art of government (Gordon 1991). The latter notion indicates that Foucault was not interested in studying the development of real governmental practices (the particular context, problems, tactics, instruments, ...) (Foucault 2008a). The art of governing points to "the reasoned way of governing best and, at the same time, the best possible way of governing" (Gordon 1991). ${ }^{22}$ Using the notion of governmentality entails that the exercise of power is intrinsically linked to the notion of knowledge. The semantic linking of gouverner and mentalite indicates that it is not possible to study technologies of power without an analysis of the rationalities underpinning them (Lemke 2001). A rationality (or reason) expresses the idea that power (of or within a system) involves not just a top-down imposition of a regime, but is rooted in a broader field of beliefs, practices and institutions (Cahill and Konings 2017a).

This brings us again to the role of the subject in the production or co-production of knowledge, and therefore, how it intervenes in power relationships. In 'Subject and Power', Foucault (1994c) clarifies that his goal was not to analyze the phenomena of power, but to perform a historical study of the different modes through which human beings are turned into subjects. In order to understand how different modes of objectivation transform human beings into subjects, a historical study is needed of the different ways in our culture on how humans develop knowledge about themselves (Foucault 1994b, c). The main point is not to accept this knowledge at face value. According to Foucault, you need to study and analyze these so-called sciences as specific truth games that are related to specific techniques (the interplay between technologies of power and technologies of the self) ${ }^{23}$ used by human beings in order to understand themselves (and others). These truths games are ongoing, because truths are not established but constructed (Foucault 1994d). In other words, these ongoing battles about developing and constructing knowledge or truths need to be grasped as being embedded inside power relationships. Foucault's interest in the relationship between the subject and truth implicitly opens up space to imagine how

\footnotetext{
Footnote 21 (continued)

also the way one governs one's wife and children. The analysis of these techniques is necessary because it is very often through such techniques that states of domination are established and maintained."

${ }^{22}$ Gordon defines it as follows on page 3 of the chapter: "a rationality of government will thus mean a way or system of thinking about the nature of the practice of government (who can govern, what governing is; what or who is governed), capable of making some form of that activity thinkable and practicable both to tis practitioners and to those upon whom it was practiced."

${ }^{23}$ In Technologies of the Self, Foucault (1994b, p. 146): defines four types of these technologies: (1) technologies of production; (2) technologies of sign systems; (3) technologies of power; (4) technologies of the subject.
} 
subjects (whether they are individuals, or groups) are involved in these truth games, because its link with power assumes a certain kind of freedom. For all these reasons, making use of the notion of governmentality in understanding neoliberalism is an important step to prevent contemplating or theorizing on neoliberalization as a mere top-down process. However, I will argue further below that something extra is required. Nevertheless, it is a first necessary step.

The notion of governmentality also complies with Leitner's (2007) claim that close empirically grounded analysis is essential to better understand neoliberalism and to imagine and create alternative urban futures (principle 1). But what is meant by 'close empirically grounded analysis'? Some academics would understand this as the move to let the field speak. Others would argue that the field never speaks. The latter is in line with Burawoy's argument (2009) that without theory we are blind and that in order to comprehend reality (data), we always rely on concepts and theories. ${ }^{24}$ This idea is central for scholars who rely on a reflexive or interpretative approach. For them, understanding is more like a process which will inevitably be determined by the interpreter and his own historical and cultural background (Bogaert 2011; Burawoy 2009). Proponents of the interpretative approach assert that the process of understanding implies two things: (1) the process of understanding is mediated by the positionality of the researcher; (2) the process of understanding involves more than just the reproduction or discovery of an observable reality (Bogaert 2011). It is also a productive activity: facts are made, knowledge is produced. According to Bogaert (2011), theory plays a determined role in the production of knowledge, since empirical data are, like knowledge more generally, always produced through the theoretical lenses that have been produced and used in different fields. ${ }^{25}$ As a scientist, it is of course very hard to escape from this. ${ }^{26}$

Nevertheless, using Foucault's notion of governmentality makes it possible to comply with principle 1 in an innovative way. It approaches a particular form of conduct not primarily from the perspective of what it might mean (as it is rationalized by one particular notion, or for example by its own hegemonic self-representation or truth), thereby using some standard definition as if it has an existence independent of the activities of its contestation and study (Parker 2016). ${ }^{27}$ Using the notion of

\footnotetext{
24 See also (Burawoy 1998).

${ }^{25}$ It is indeed this dwelling in theory in order to produce facts and knowledge that is at the basis of a reflexive or interpretative approach of knowledge production that thematises our presence in the world we seek to describe and explain (Burawoy 1998) For specifics: See (Burawoy 1998).

${ }^{26}$ A great example of the latter is Sassen's work on expulsions where she argues that empirical research and conceptual recoding must happen together (Sassen 2014). Rather than giving meaning to facts by processing them upward through theorization, Sassen claims to do the opposite, bringing them down to their basic elements in an effort to de-theorize them. By doing this, she claims that she can revisit then inequality, finance, mining, ... in order to see what we miss with more abstract categorizations. However, in practice, what she does is not detheorize in order to retheorize, but simply 'theorizing'. Nevertheless, not only actors of conduct or scientists are producing modes of veridiction. Also, actors of counter-conduct are producing knowledge.

27 According to Parker (2016): "social movements do not simply respond to, or struggle against, a world that is "out there",- - they do not face a hegemony that is always already fully formed-they intervene in ways that shape and potentially transform the spatial fabric within which contention unfolds ... There is a tendency to frame social movements and contentious politics in terms of resistance-as struggles
} 
governmentality is related with a specific method Foucault (2008a) is using in his work. He does not start from given objects or universals (such as the sovereign, the state, ...), but he does the opposite: he starts from practices as it reflects on itself and is rationalized (by actors in that particular time-frame) to show how certain things (for example state, market) were able to be formed or to become possible.

What Foucault is using is a genealogical approach (Lemke 2001). ${ }^{28}$ How to define such an approach (Dean 2010b) ? ${ }^{29}$ It is the method that (1) traces the emergence of an (abstract) notion, phenomenon or process that (in its contemporary form) is taken for granted and by doing this (2) the aim is to de-essentialize this notion instead of searching for its causal origin or original starting point. It is an attitude adopted to limit two tendencies: (1) to read or study the past through the experience of the present or that you cannot rely on the use of notions of the present (universals); (2) to read or study the present through the experience of the past. Because if you do, the danger exists that you will interpret certain outcomes at the present as linked to a singular inevitable cause or origin; thereby drawing a linear line. Foucault (2008b, p. 49) defines it as follows in Birth of Biopolitics.

In contrast with a genesis oriented toward the unity of an originating cause pregnant with a multiple descent, genealogy tries to reconstruct the conditions of the appearance of singularity on basis of the multiple determining elements, from which it arises not as the product, but as the effect.

The way how genealogy is embedded in Foucault's notion of governmentality could best be understood as his endeavor to indicate that moment or the process through which a particular set of discourse and a set of practices are linked with each other (Foucault 2008a). A discourse that "on the one hand constitutes these practices as set bound together by an intelligible connection and on the other hand legislates and can legislate on these practices in terms of true and false" (Foucault 2008a, p. 18). Foucault conceptualized this as a regime of truth. What he tried to do is to show how a set of practices and regime(s) of truth evolve and become linked together in order to form an apparatus of knowledge power "that marks out in reality that which does not exist and at the same time legitimately submits it to the division between true and false" (Foucault 2008a, pp. 18-19).

Important to acknowledge is the link between Foucault's method on genealogy and his understanding of critique. In 'What is Enlightenment', Foucault (2007e) gave

\footnotetext{
Footnote 27 (continued)

against power. But social movements do not only struggle against, they also struggle for. They must come together to build a different world, to articulate a different kind of power. To borrow a line from Timothy Mitchell (2008), a social movement needs to make 'sites where its facts can survive'." Therefore, it is interesting to study the way how social movements or actors of counter-conduct approach upon and define notions as neoliberalism.

28 Lemke argues on page 190-192 that Foucault in his lecture series is "tracing the genealogy of governmentality from Classical Greek and Roman days via the early Christian pastoral guidance through to the notion of state reason, the liberal and neoliberal forms of government.".

${ }^{29}$ In what follows I rely on the different readings of Foucault in the bibliography and the chapter on Genealogy written by Dean (see references in text).
} 
a more positive content to the notion of critique. Acknowledging that the notion of criticism consists of analyzing and reflecting upon limits, Foucault (2007d, e) transforms the Kantian critique conducted in the form of a necessary limitation into a practical critique that takes the form of a possible transgression. ${ }^{30}$ At this point, he transforms or links the notion of critique to his own critical methods: archaeology and genealogy (linked to his notion of governmentality as exemplified above) (Karskens 2012). In 'What is Enlightenment', Foucault (2007e, pp. 113-114) argued that this criticism is genealogical in its design and archaeological in its method:

Archaeological - and not transcendental - in the sense that it will not seek to identify the universal structures of all knowledge or of all possible moral action, but will seek to treat the instances of discourse that articulate what we think, say, and do as so many historical events. And this critique will be genealogical in the sense that it will not deduce from the form of what we are what it is impossible for us to do and to know; but it will separate out, from the contingency that has made us what we are, the possibility of no longer being, doing, or thinking that we are, do, or think. It is not seeking to make possible a metaphysics that has finally become a science; it is seeking to give new impetus, as far and wide as possible, to the undefined work of freedom.

Foucault (2007e, p. 113) detaches the notion of critique from the search for formal structures with universal value and turns it into a historical investigation into "the events that have led us to constitute ourselves and to recognize ourselves as subjects of what we are doing, thinking and saying ".

This brings us again to the relationship between power and knowledge/truth. The struggle for power is also a struggle for truth, since truth is not outside power and vice versa (Foucault 1994d). Foucault explained that by truth he did not mean the ensemble of truths to be discovered and accepted, but rather the ensemble of rules according to which the true and the false are separated. Therefore, we should not think in terms of a battle on behalf of the truth, but about the status of truth. According to Foucault, the problem for an intellectual is not to change people's consciousness, but the political, economic, and institutional regime of the production of truth. His critical method consists in showing how truth is produced and how its regimes of truth emerged and came into being. By doing this he fulfills his role of the intellectual that needs to open the space in which to think about how it is possible to think in a different fashion (Dean 2010a).

Consequently, decentering neoliberalism also means to be aware of and to elaborate on neoliberalism's own beginnings as a project of contestation and change (principle 2) (Leitner et al. 2007). A genealogical viewpoint makes you aware that the emergence of neoliberalism must not be seen as inevitable or determined by its natural superiority as a regime of truth or by an unescapable logic of capital and class power. According to Lemke (2001), the notion of governmentality construes

\footnotetext{
30 According to Foucault, the Kantian notion of critique was about knowing what limits knowledge has to renounce transgressing (in the context of course of the absolute king). In other words, according to Kant the courage to know also entailed recognizing the limits of knowledge.
} 
a way of governing (for example neoliberalism) not just as ideological rhetoric or a political-economic reality, but as a political project that attempts to create a reality suggesting it already exists. It entails a project that in a sense is never finished and has to be seen as a process rather than a clear end status, and therefore, will interact with existing practices and imaginaries.

Because of this, it is not enough to study neoliberalism's rise to hegemony (it is even counterproductive taking into account the remarks by Purcell, Pinson and Morel Journel) by only theorizing on neoliberalization (Leitner et al. 2007). Whereas contextualizing neoliberalism is important, Leitner argues that it is also necessary to examine its articulation with contestations within and beyond the state that have shaped and will continue to influence the conditions of its possibility. Applied to the historical example of the shift toward a political notion of the conduct of conduct, Foucault (2008a) did not argue that the transition from a territorial state to a population state emerged as a mere substitution of the former by the latter, or that there is a logical sequence in the evolution of juridical, disciplinary, and security techniques. Concerning neoliberalism, some critics have interpreted it (mistakenly) as a new paradigm of power that would supersede older forms of disciplinary power (Hamann 2009). Just as the element of the Raison D'État were not immediately, entirely wiped out by the new governmental reason of Liberalism, it is always necessary to indicate the complex ways in which different forms of power have co-existed and complemented each other.

\section{(Re)introducing the notion of counter-conduct in the governmentality approach}

In the preceding paragraphs, I showed that by using the notion of governmentality (in combination with the method of genealogy) the first two principles and one basic condition (or entrypoint) in order to decenter neoliberalism in the analysis could be fulfilled. However, in many studies, governmentality is only used in order to grasp what exactly neoliberalism is and how it works. Whereas the impact of Foucault on research of power is clear, you could doubt if the same is true for research on contentious politics and social movements. Death (2010) asserts that his use of concepts as power/knowledge, biopower, ... have influenced scholars in the way they think and theorize about non-state and adversarial forms of politics. Nevertheless, Death also argues that we should not overestimate Foucault's direct impact on contemporary social movement studies and research on contentious politics. O'Mally for example asserts that governmentality studies have been seemingly reluctant to address contestation and that in many cases resistance only appears as a failure (Death 2010). Also, in the key governmentality texts, there is little space given to social movements and contestation. A similar remark is made by Mayer and Boudrieu who claim that post-structuralist analyses of social movements contesting urban neoliberalization are relatively sparse (Mayer and Künkel 2012).

Bulley (2016), Cadman (2010) and Death (2010) make this more specific by arguing that one particular notion had been given very little attention in current research: the notion of counter-conduct and the mode of questioning found therein which concerns "how not to be governed". What Foucault (2007a) tried to do was to 
find a notion that can be used to designate the type of revolts or resistance to forms of power that do not exercise sovereignty and do not exploit, but conduct. ${ }^{31}$ The remarks by Bulley, Cadman, and Death are in line with the belief that Foucault had more to say about regimes of power than he did about forms of resistance or alternative politics (Death 2010). Bulley (2016) even argues that Foucault himself gave the concept very little attention. ${ }^{32}$ I will reflect on a possible explanation for this more below. Whatever the reason may be, it is a fact that much of the current literature in the field of governmentality studies seek to outline the regimes of truth through which governors govern (Cadman 2010).

This is a limited understanding of governmentality, especially when you acknowledge that the possibility of dissent and resistance are at the heart of Foucault's philosophy (Death 2010). Bully (2016) argues that Foucault's interests led him to understand the history of government as the conduct of conduct to be intrinsically linked with the history of counter-conducts. Indeed, for Foucault the analysis of governmentality is inseparable from analyzing the corresponding modes of counter-conducts (Senellart 2007). According to Death (2010), Foucauldian political thought has more to contribute to questions of contestation, social movements and change, and in particular regarding the relationship between power and protest. But Foucault's relevance for the study of counter-conduct should and can be made more explicit. In particular, the notion of counter-conduct can be used to develop an analytics of protest for the study of contentious politics. Although Death applies this analytics of protest to the summit form, he argues that a Foucauldian-informed approach can be provided to the study of contentious politics and protests in a far broader range of contexts.

I argue that making use of the notion of governmentality is not enough in order to go beyond or to decenter neoliberalism. Or to state it more specific: making use of the limited notion of governmentality is not enough. By (re-)introducing the notion of counter-conduct (which Foucault (2007d) links to the notion of critique) and by making it more explicit in the governmentality approach, scholars can move beyond a one-directional understanding of governmentality (Bulley 2016; Cadman 2010; Death 2010).

Contestation is conceptualized as more than just resistance to neoliberalism (principle 3) Much of the social movement literature has tended to conceptualize resistance as the act of opposing power (Death 2010). While Foucault introduced the notion of counter-conduct to denote forms of struggle or revolt against the processes implemented for conducting others, counter-conduct did not necessarily require a rejection or absolute opposition of government in general (Odysseos et al. 2016). The emergence of counter-conduct entails a constant activity of questioning about the way to govern and how we are governed. More in particular it asks: "how not be

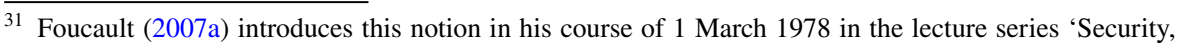
Territory and Population'.

${ }^{32}$ Nevertheless, Bulley (2016) nuances this by explaining that Foucault's interest "lies in the way that the history of government as the conduct of conduct is interwoven with the history of dissenting counterconducts.".
} 
governed like that, by that, in the name of those principles, with such and such an object in mind and by means of such procedures, not like that, not for that, not by them" (Odysseos et al. 2016, p. 153); (Foucault 2007d, p. 44). ${ }^{33}$

This reflects the impossibility of drawing clear distinctions between power and resistance. Resistance is coextensive and absolutely contemporaneous to power (Davidson 2011). Foucault had already insisted in 'The Will to Knowledge' that resistance is not in a position of exteriority with respect to power. It is more correct to think of resistance as existing in a strategic field of relations of power and relations of power themselves only exist relative to a multiplicity of points of resistance. It led Foucault to pronounce the following quote: "Where there is power, there is resistance" (Davidson 2011, pp. 27-28). In 'Security, Territory and Population', Foucault also emphasized the non-exteriority, the immanent relation, of conduct and counter-conduct. In addition, it is also important to apply Cadman's preemptive stance toward counter-conduct in order to go beyond a mere understanding of counter-conduct as a post hoc reaction or response to governmental regimes of truth (Cadman 2010). ${ }^{34}$ Also, because a governmental regime of truth is never fully established. Which is related to the following principle.

Contestation and neoliberalism are conceptualized as co-implicated (principle 4) By destabilizing conventional binaries between power and resistance, using the notion of counter-conduct in a governmentality approach exemplifies how protest/ contestation and government are mutually constitutive (Death 2010). This destabilization makes you aware of the fact that forms of contestation have the potential to reinforce dominant forms of governance as well as undermining and challenging them. According to Cadman (2010), governmental counter-conducts are not merely additional or reactive but are wholly immanent and necessary to the formation and development of governmentality.

Focus on a wide range of robust alternative imaginaries and practices (principle 5) Another implication of the abovementioned assumption of binary opposition is that movements themselves can be categorized as either revolutionaries or collaborators (Death 2010). According to Death, this is part of an actor-centric approach that is a common feature of many existing analyses of protest. These analyses tend to address the origins, motivations, successes, and failures of protests of particular groups, that are often primarily based on activist testimonies. Death claims that implementing the idea of counter-conduct in the governmentality approach does not study protest and contentious politics from such an actor-centric perspective, but rather orientates itself toward practices and rationalities/mentalities of contestation

\footnotetext{
${ }^{33}$ Counter-conductive struggles, then, according to Odysseus et al. (2016, p. 153) may not explicitly "look for the chief enemy, but for the immediate enemy, not always the state as governor par excellence, but governors in the plural, resulting in attempts to resist, escape and involute rationalities and technes of conduct, or the art of not being governed quite so much.".

34 In this remark you already see why it is important to start with the notion of counter-conduct. Cadman explains her preemptive stance as follows (Cadman 2010, p. 540): "It is to counteract the possibility that, as the term is taken up and developed, it will share the same problematic fate as that of Foucauldian 'resistance' and 'subjugated knowledge' before it. That is, by becoming understood as a post hoc reaction or response to governmental 'regimes of truth'."
} 
"that work to constitute particular identities and subjectivities through the performance of dissent". According to Leitner et al. (2007), the role of neoliberalism in shaping change is decentred further when you focus on a wide range of alternative practices and rationalities (external to the explicit notion of counter-conduct in relation to neoliberalism) This is of course related with the notion of contingency: Leitner and colleagues do not wish to prejudge any outcome. They argue that although neoliberalism could gain complete hegemony, it could also be replaced by another imaginary and practice or another thing to occur would be ongoing contestation among capitalists and non-capitalist imaginaries and practices.

Conceptualize contestation as exceeding neoliberalism (principle 6) By focusing on practices/mentalities of contestation, it is also possible to conceptualize contestation as exceeding neoliberalism. Leitner et al. (2007) correctly argue that although much contestation has emerged as a direct or indirect response to neoliberalism, restricting the domain of analysis to this category of contestation is to concede the center to neoliberalism. Sites (2007) argues that it is not always easy to detect the anti-neoliberal character of uprisings and protests. Many of these groups do not explicitly link the threats they face to the workings of neoliberal capitalism, nor do they necessarily connect their own action to larger struggles (Kruithof 2000). ${ }^{35}$ Therefore, Leitner et al. (2007, pp. 5-11) argue that defining contestation needs to exceed neoliberalism, in order to conclude and take into account the diversity of imaginaries and practices. Paying attention to the complexity of interactions among rival contestants has the potential to decentralize neoliberalism as just one contestant among many. It also makes visible those practices that go beyond mere resistance or are resilient and therefore have the potential to rework neoliberalism.

\section{Going beyond one important limit}

\section{Why re-introducing the notion of counter-conduct is not enough}

What does it mean to re-introduce the notion of counter-conduct in the governmentality approach in order to move beyond the one-directional understanding of power (Bulley 2016; Cadman 2010; Death 2010)? You could argue that the act of

\footnotetext{
35 Against this background, some academics even argue-in contradiction to much of their colleaguesthat they are not convinced about the link between the uprisings in 2011 (such as Arab Spring, Occupy, ...) and neoliberalism. For example, Ishkanian and Glassius (2018) who studied square activists in three cities (Athens, Cairo and London) contend that anti-neoliberal is an inadequate label for describing the political stances of the activists in these three cities. Others also have raised some doubts about the link between these uprisings and the urban scale/aspect (of neoliberalism). A dominant framework for analyzing cities and social movements is 'the right to the city literature' (Uitermark et al. 2012). Authors relying on this framework claim that mobilizations within cities arise in response to neoliberal urbanization. In an article dealing with the Tunisian uprisings of 2011, Zemni (2017) points to the limits of this approach and raises some doubts if such types of protests may be 'lumped together' with the wave of urban uprisings in the last decade (from the Arab Spring to Puerta del Sol. In concrete, Zemni (2017, pp. 10-11) argues that "the complexities of the local history and development of contentious politics also reveal specificities that make the lumping together of the Tunisian case with worldwide urban uprisings questionable."
} 
merely re-introducing the notion of counter-conduct is quite paradoxical. Because, this notion is embedded in and intrinsically linked to the notion of governmentality. Foucault's notion of governmentality is situated in the study of power relationships in which the exercise of power entails a complex interplay with the condition of freedom (Foucault 1994c). In the 'Subject and Power', Foucault (1994c, p. 139) argues that:

At the very heart of the power relationship, and constantly provoking it, are the recalcitrance of the will and the intransigence of freedom. Rather than speaking of an essential antagonism, it would be better to speak of an "agonism" - of a relationship that is at the same time mutual incitement and struggle; less of a face-to-face confrontation that paralyzes both sides than a permanent provocation.

Sennelart (2007, pp. 398-391) asserts that for Foucault "the analysis of types of governmentality is inseparable from the analysis of corresponding forms of resistance or counter-conducts." Contestations always emerge within (and against) the notion of governmentality because of the intrinsic relationship between power and freedom, or as a result of the encounter between technologies of power and technologies of the self (which Foucault (1994b) defined as governmentality).

Because the notion of governmentality is intrinsically linked to the method of genealogy, it prevents you from interpreting the emergence of neoliberalism as inevitable (Lemke 2001). The notion of governmentality (in combination with the method of genealogy) starts from the recognition of an interplay between discourses and practices thereby accepting the notion of change and contingency. The ways in which rationalities evolve and change make visible that the government of men is a practice which is not simply imposed by those who govern upon those who are governed (Cadman 2010; Foucault 2008a). A regime is not imposed by either one side or the other, but occurs through interaction and transaction between the actors of conduct and actors of counter-conduct. This process is characterized by conflicts, crises, agreements, disagreements, discussions, concessions, and so forth.

The act or move to (re-)introduce the notion of counter-conduct brings us to the question why researchers-including Foucault - gave to this notion so less attention. There is a danger in assuming that the notion of counter-conduct is intrinsically linked to a particular type of governmentality and that it only needs to be reintroduced or recovered. Instead, the notion of counter-conduct needs to be made more explicit in a sustainable way. Otherwise, you risk that after (re-)introducing counter-conduct, this notion starts to shift and change in a way that is described by Davidson.

Davidson (2011) points to the absence of the notion of counter-conduct in Foucault's lecture series of 1979 Birth of Biopolitics. He argues that the relationship between 'Security, Territory and Population' (where counter-conduct appears as a key concept) and 'Birth of Biopolitics' (where it is not mentioned once) can only be approached by keeping in mind the ambiguity of the very notion of conduct (Davidson 2011). 
At one level, it is an ethico-political activity and at another level it is a scientific-epistemological object. ${ }^{36}$ Davidson (2011) asserts that a major problem arises when the notion of conduct is displaced from an ethical and political context and is inserted into a scientific and epistemological framework. In 'Birth of Biopolitics', Foucault studied the notion of conduct (in the context of the examination of the neoliberal homo oeconomicus), by focusing on the economists themselves, and as a consequence, it only emerges as part of a scientific-epistemological framework. In other words, conduct becomes embedded (and even subordinated to) in-what Foucault defines as - a regime of veridiction (that of economic conceptualization and explanation) that not only restructures the concept of conduct, but also of counter-conduct. Davidson (2011) argues that this intellectual move has major consequences: (1) the notion of conduct as ethical and political action is completely neutralized; (2) conduct as scientific object is constituted and detached from counter-conduct as a fully ethical and political activity. ${ }^{37}$ The result is the conceptual disappearance of counter-conduct and the reduction of the latter to nothing more than a form of irrationality or abnormality. ${ }^{38}$ It is obvious that regimes of veridiction or truth are closely related to regimes of scientific veridiction: "When a regime of scientific veridiction provides the framework of intelligibility for conduct, this concept completely changes register, losing its ethical and political dimensions and becoming the object of scientific explanation" (Davidson 2011, p. 36).

These remarks by Davidson are related to Sites' claim (2007) that how one conceptualizes the fundamental operations of capitalism may have important implications for the analytical valence of oppositional challenges. How you understand the nature of contestation may depend on how neoliberalism (or neoliberal capitalism) is conceptualized. If conduct (of conduct) is displaced from its political context and is studied through the framework of a particular regime of veridiction, it could reproduce itself and counter-conduct can become inconceivable or irrelevant. It is exactly at this point where the danger is situated for social scientists in not only producing and reproducing neoliberalism, but also of its hegemonic character (and thus their own cage).

\section{The way forward}

The insights of Davidson exemplify that it is not enough to merely assume the presence of the notion of counter-conduct in the governmentality approach. The question that we need to tackle is how to (re-)introduce the notion of counter-conduct in a sustainable way or to make it more explicit so that it does not disappear or change register. Therefore, we need to focus on how the seventh principle of decentering needs to be applied in practice: Starting-not with neoliberalism-but with its

\footnotetext{
36 In what follows is based entirely upon the work of Davidson (pp. 36-39).

37 It is useful to remind us to Foucault's remark that "politics is no more or less than that which is born with resistance to governmentality" (Senellart 2007, p. 390).

38 Davidson argues to be attentive to this substitution of counter-conduct with pathology and to resist the psychologization of conduct.
} 
articulation with contestation (principle 7). Leitner et al. (2007) argue that in order to prevent taking the internal logic of neoliberalism as a starting point, they claim not to start with neoliberalism, but with its articulation with contestation.

The aim of analyses that takes the struggle itself as a starting point is to prevent reading resistances off a reified account of power and order (Coleman and Rosenow 2016). In order to grasp the complex interplay between power and resistance, you need to prevent that the evaluation of the potential of change has already been decided in the framing of this object of study. Starting with the struggle itself implies that the use of ready-made subjects and pre-defined fields needs to be prevented. But starting with the struggle is not enough. Leitner and colleagues (2007) already pointed out that research on neoliberalism and contestation usually begins with neoliberalism, regarding contestation as secondary and reactive. This means that these studies focus on how neoliberalism articulates with its direct contestation.

Even though you take the struggle as a starting point, if you start from neoliberalism you still risk to essentialize the latter's logic. This has great consequences for the notion of counter-conduct which brings us back to the insights of Davidson (2011). The way how Foucault analyzed forms of governmentality through timeespecially when he focused on neoliberalism-resulted in the fact that these contestations or counter-conduct conceptually disappeared. Taking the rationality of power constellations as the entrypoint in your analysis makes it impossible for contestation to be grasped and detected as counter-conduct in its pure meaning of how not to be conducted in that particular way. This explains that these analyses make it almost impossible for the researcher to notice, analyze, and evaluate a different set of relations and practices.

Studying the notion of counter-conduct without making it a-priori inconceivable or irrelevant-by displacing (counter-)conduct from a political into a merely scientific-epistemological framework)-implies bringing back the notion of counter-conduct in the political context (and keeping it there). In order to achieve this, I argue that the seventh principle needs to be refined. In the context of taking the struggle as an entrypoint, (I) a necessary step is to start from or focusing on the notion of counter-conduct as imaginaries and practices in order to study (1) not only how counter-conduct articulates with neoliberalism, (2) but also how counterconduct articulates with other forms of conduct (Leitner et al. 2007). ${ }^{39}$ This means that one has to focus on both practices and rationalities/imaginaries of counter-conduct (Death 2010).

Central in the extended notion of governmentality is that counter-conduct becomes the entrypoint of the analysis. I do not even assume the existence of a neoliberal governmentality, because the study does not start with analyzing the notion of neoliberalism. The extended notion of governmentality entails what Foucault asserted in 'Subject and Power' but did not apply in his studies on (neoliberal) governmentality. In 'Subject and Power', Foucault (1994c, pp. 128-129) suggests to study power by "taking the forms of resistance against different forms of power as a starting point." The idea is to study power not "from the point of view of its internal

39 Leitner and colleagues speak in terms of other forms of capitalism. 
rationality, but by means of analyzing power relations through the antagonisms of strategy."

This brings me to the second necessary step (II) Starting from counter-conduct as it reflects on itself and is rationalized by actors of counter-conduct, other than the one who observes and/or theorizes. I argued above that theory plays a determining role in the production of knowledge, since empirical data are, like knowledge more generally, always produced through the theoretical lenses that have been produced and used in different fields. As a scientist, it is of course very hard to escape from this. Nevertheless, this is what Foucault tried to do by not talking about certain concepts in order to de-theorize, refraining from taking certain notions as universals. He starts from practices as is reflects on itself and is rationalized by certain actors (both governing and the ones being governed) (Foucault 2008a).

These two steps are central in the extended governmentality approach as method: (1) the first step entails centralizing of what is intrinsic inside the notion of governmentality but could not be taken for granted - a field of possibilities-by means of taking counter-conduct as the entrypoint of any analysis of power and change; (2) the second step is taking a genealogical attitude as a precondition to study counterconduct. Only in the context of these steps that are the central elements inside the (extended) governmentality approach, the notion of governmentality can be used as a concept. Governmentality as a concept refers to the reasoned way of governing best, or from the perspective of the notion of counter-conduct the reasoned way of governing differently. In other words, Foucault's working hypothesis on the reciprocal constitution of power techniques and forms of knowledge also applies on the notion of counter-conduct: it is indeed not possible to study the technologies of counter-conduct without an analysis of the rationalities/imaginaries underpinning them. Not only actors of conduct or scientists are producing modes of veridiction. Also, actors of counter-conduct are producing knowledge.

The notion of counter-conduct is clearly focused on certain notions of conduct (that in the literature is described as being hegemonic or dominant), and therefore, it is necessary not to approach this particular form of conduct primarily from the perspective of what it might mean, but you start from the practices as they are rationalized and (re)constructed by different actors. In this case the actors of counter-conduct (Foucault 2008a). Nevertheless, the reasoned way of governing differently entails that besides analyzing and critiquing the actual knowledge-power apparatus, you also need to rationalize about those practices that are considered as the best possible way of governing. In concrete, I discern three elements in the notion of governmentality understood as the reasoned way of governing best or the reasoned way to govern differently: (1) analysis of society/environment; (2) an alternative or utopia; (3) instruments/strategies to go from (1) to (2). These three elements could be translated in the following questions where you can rely on in the study of the reasoned way of governing best: (1) What aspects of conduct are problematized and therefore become the object of intervention? (2) What alternative notions of conduct are elaborated on? (3) What strategies/instruments are applied in order to make changes in the conduct of conduct and the conduct of the self?

Using this approach has two main advantages. First, you comply with the critique of Pinson and Morel Journel (2016) by not neglecting the description of ideological and 
practical alternatives (in a way that does not result in inhibiting the emergence of alternatives). It also provides progressive forces a better grip on reality and the possibilities that exist to change the existing order. This approach provides the social scientist with the tools to detect seeds of progressive change and appreciate the possibilities that exist to change the existing order. Second, it provides progressives forces a better grip on reality tout court. This approach is not only useful in order to fully understand the actual power relations and effects at work, but it can also provide an explanation why actors of counter-conduct or counter-conduct fail to change the current order. It is at this point where the notion of critique detaches itself of the notion of counter-conduct in which the latter becomes the case under investigation of the former. In 'What is Critique' Foucault (2007d, p. 44) linked the notion of critique immediately as an attitude or practice to the actors of counter-conduct who are driven by the question: "how not to be governed like that, by that, in the name of those principles, with such and such an objective in mind and by means of such procedures, not like that, nor for that, not by them." Critique is resistance against the governing power or instance (Karskens 2012).

According to Foucault (2007d), the core of critique is not only focused on power as such, but on the relationship between power, truth, and subject. Whereas Foucault's critical method consists in showing how the truth is produced and how its regimes of truth emerged, his notion of critique could also be used to study how truth is not produced (Foucault 1994d). In other words, to study how actors of counter-conduct (activists, politicians, critical academics, ...) fail to interact with the regime of truth and to change the latter. If the role of the intellectual consists in the act of opening space in which to think about how it is possible to think in a different fashion (Dean 2010a), another task of the intellectual is to study how critical actors are closing that same space to think differently by studying how they use concepts and define the existing order. Because the way how actors of counter-conduct or critical academics use concepts have an impact on the way they are contemplating and producing change. As such the actor himself is not directly liberated but is shown how reality is perceived and the impact this has on the way he or she is trying to change it. Decentering neoliberalism does not only occur at the level of the researcher who conducts research, but also at the level how others are representing and (re)producing a particular world.

\section{Conclusion}

Following the dawn of the great mobilizations of 2011, observers became increasingly reluctant to announce the beginning of the new post-neoliberal era. Neoliberalism's capacity to turn crisis into reinvention led some to wonder whether its hegemony had been consolidated rather than undermined in the wake of the financial crisis of 2008. When Zhou Enlai was asked about his opinion of the French Revolution, he answered "Is it not a little too early for a definitive answer?" (Doom 2012, p. 4). Perhaps, it was also too early to reconfirm neoliberalism's hegemonic status.

In 2019, millions protested on the streets of cities in Algeria, Sudan, Chile, Lebanon, Iraq, Hong Kong, Ecuador, Haiti, Guinea, Bolivia, Spain, France, Brazil, Iran, Czech Republic, Colombia, India, ... (Bogaert 2020). All these protests do remind us of the global uprisings of 2011, and these should be interpreted as part of the 
same process. The Covid-19 crisis facilitated the reopening of the debate about the status of neoliberal capitalism. According to Saad-Filho (2020, p. 482), neoliberal capitalism has shown its incapacity to tackle the crisis. Because of this, he is quite optimistic that, this time, "capitalism cannot wash this stain." Bregman (2020) and Lent (2020) are also quite convinced about the end of neoliberalism, and they already reflect on the further trajectory of the post-neoliberal order. Ten years ago, the opponents of neoliberalism were united in their rejection of austerity, the elite, the system and so forth, but had no blueprint of an alternative system. Today, Bregman claims, alternatives are all around us, ready to be used and implemented. Other observers, however, are more cautious in declaring neoliberalism's defeat (VargasGómez 2020).

I also plead for more caution, not because things are not changing, but because it is way too early to say what these changes might mean. We should pay careful attention to how our approaches to the study of alternative practices and ideas shape our perception of how they interact with, and what they mean for, the current and emerging political-economic order. How should we study social change in a way that does not presuppose a certain outcome, thereby preventing both an overly optimistic and an overly pessimistic viewpoint? The great danger is that scholars, even those who are convinced that what we are seeing is neoliberalism's final crisis, become (again) obsessed with neoliberalism.

This obsession is both cause and effect of putting neoliberalism and its perceived logic central in the analysis. The consequences are twofold. First, it inevitably leads you to neglect or to put less effort in detecting, describing, and explaining alternative practices and rationalities. This indirectly contributes to a tendency of concealing and inhibiting the emergence and consolidation of these alternatives. Second, by making neoliberalism the middle-point of analysis, the risk is that all other alternative practices and rationalities will be reduced or linked to a neoliberal force and logic (or neoliberal forces when you replace the Big-N Neoliberalism for small n-neoliberalisms or neoliberalizing processes) (Springer 2012; Wacquant 2012). Pinson and Morel Journel (2016) argue that when you reduce all transformation in (urban) society to a neoliberal force, this does not only deprive you (the observer) but also the actors of change themselves of a more complete vision of ongoing change and its concrete mechanisms.

As a consequence, the effort put into crafting theories and interpretations of the current status of the neoliberal order could lead you vast but slowly to an underestimation of alternative practices and rationalities in its attempt to change and modify that order. Even when your explicit aim is to "acknowledge the power of neoliberalism without reinscribing it as a unitary hegemonic project" (England and Ward 2007 , p. 251), the danger of starting with neoliberalism in your study is that in the end you realize that you have been feeding the hegemonic beast that you pretend to slay in the first place. In this context, the remark of Sites (2007) is still relevant: how you conceptualize the fundamental operations of early twenty-first century (neoliberal) capitalism may have important implications for the analytical valence of oppositional challenges. We need to make sure that the reopened debate does not redirect us once more to the conclusion how flexible and crisis prone the neoliberal order actually is. 
In order to prevent this outcome in the study of how neoliberalism articulates with its contestations, I turned to the work of Leitner and others who developed a research agenda in order to decenter neoliberalism in the analysis of contestation and change. I argue that Foucault's (extended) governmentality approach could be used as a method in order to turn this agenda of decentering into practice. The adjective "extended" adds an important insight that Foucault shared in 'Subject and Power', but did not apply in his own lecture series on the neoliberal governmentality. In 'Subject and Power', Foucault (1994c, pp. 128-129) points to the imperative of studying power by "taking the forms of resistance against different forms of power as a starting point". The idea is to study power not "from the point of view of its internal rationality, but by means of analyzing power relations through the antagonisms of strategy." Central in this extended approach is to start from the actors of counter-conduct and how it reflects on itself and on its self-proclaimed art of governing, not only with the objective to understand and analyze power relations, but how they are changed.

Acknowledgements I wish to thank Professor Christopher Parker (Ghent University) for the discussions that inspired me to write this article.

Funding This study was conducted in the context of a doctoral scholarship funded by the Special Research Fund (BOF) of Ghent University.

\section{Compliance with ethical standards}

Conflict of interest The author declares that he has no conflict of interest.

\section{References}

Barnett C (2005) The consolations of 'neoliberalism.' Geoforum 36(1):7-12. https://doi.org/10.1016/j. geoforum.2004.08.006

Behrent MC (2016) Conclusion: the strange failure (and peculiar success) of Foucault's Project. In: Zamora D, Behrent MC (eds) Foucault and neoliberalism. Polity Press, Cambridge, UK, pp $176-186$

Bogaert K (2011) Chapter 1: Method, fieldwork and critique as methodology. In: Bogaert K (ed) Urban Politics in Morocco: Uneven development, neoliberal government and the restructuring of state power. Gent, pp 23-51

Bogaert K (2020) Can we think the global revolution? From the Haitian revolution to the spectre of Tahrir. Open Democracy. https://www.opendemocracy.net/en/north-africa-west-asia/haitian-revolution -spectre-tahrir-global-revolution-possible/

Bregman R (2020) Het tijdperk van het neoliberalisme loopt ten einde: wat komt ervoor in de plaats? De Correspondent

Bulley D (2016) Occupy differently: space, community and urban counter-conduct. Glob Soc 30(2):238-257. https://doi.org/10.1080/13600826.2015.1133567

Burawoy M (1998) The extended case method. Soc Theory 16(1):1-33

Burawoy M (2009) Introduction: from Manchester to Berkeley by Way of Chicago. In: Burawoy M (ed) The extended case method: four countries, four decades, four great transformations and one theoretical tradition. University of California Press, California, pp 1-18

Burchardt M, Kirn G (2017) Chapter 1: Beyond neoliberalism? Social analysis after 1989. In: Burchardt M, Kirn G (eds) Beyond neoliberalism: Social analysis after 1989. Palgrave MacMillan, New York, pp 1-14 
Cadman L (2010) How (not) to be governed: Foucault, critique, and the political. Environ Plan D 28(3):539-556. https://doi.org/10.1068/d4509

Cahill D (2014a) 2. Actually existing neoliberalism. In: The end of Laissez - Faire? On the durability of embedded neoliberalism. Edward Elgard Publishing Unlimited, Cheltenham, UK, pp 14-30

Cahill D (2014b) The end of Laissez-Faire? On the durability of embedded neoliberalism. Edward Elgar Publishing Limited, Cheltenham UK

Cahill D, Konings M (2017a) Introduction. In: Cahill D, Konings M (eds) Neoliberalism. Polity, Cambridge, UK, pp 1-25

Cahill D, Konings M (2017b) Neoliberalism. Polity Press, Cambridge, UK

Calhoun C, Karaganis J (2001) Critical theory. In: Ritzer G, Smart B (eds) Handbook of social theory. Sage, London, pp 179-200

Centeno MA, Cohen JN (2012) The arc of neoliberalism. Ann Rev Sociol 38(1):317-340. https://doi. org/10.1146/annurev-soc-081309-150235

Clarke J (2008) Living with/in and without neo-liberalism. Focaal 51:135-147

Coleman LM, Rosenow D (2016) Mobilisation. In: Bilgin P, Guilaume X (eds) The Routledge handbook of international political sociology. Routledge, New York, pp 1-12

Coolsaet R, Lesage D, Kleijsen J, Van Kerchove S (2006) Hoofdstuk 7: Transitie. In: Coolsaet R, Lesage D, Kleijsen J, Van Kerchove S (eds) Anarchie, orde, dominantie: Inleiding tot de theorie van de internationale betrekkingen. Academia Press, Gent, pp 241-310

Davidson AI (2003) Introduction (Macey D, Trans.). In: Ewald F, Fontana A, Davidson AI (eds) Society must be defended: lectures at the Collège de France. 1975-1976. Picador, New York, pp $\mathrm{xv}-\mathrm{xxii}$

Davidson AI (2011) In praise of counter-conduct. Hist Hum Sci 24(4):25-41. https://doi. org/10.1177/0952695111411625

Davidson N (2017) Crisis neoliberalism and regimes of permanent exception. Crit Sociol 43(45):615-634. https://doi.org/10.1177/0896920516655386

Dean M (2010a) Basic concepts and themes. In: Dean M (ed) Governmentality: power and rule in modern society. Sage, London, pp 16-51

Dean M (2010b) Genealogy and governmentality. In: Dean M (ed) Governmentality: power and rule in modern society. Sage, London, pp 52-74

Dean M (2016) Foucault, Ewald, neoliberalism, and the left. In: Zamora D, Behrent MC (eds) Foucault and neoliberalism. Polity Press, Cambridge, UK, pp 85-113

Death C (2010) Counter-conducts: a Foucauldian analytics of protest. Soc Mov Stud 9(3):235-251

Doom R (2006) Vrijheid en Gelijkheid

Doom R (2012) Omzien in verwarring: Een essay over democratie en het Globale Zuiden. Academia Press, Gent

Duménil G, Lévy D (2005) The neoliberal (counter-)revolution. In: Saad-Filho A, Johnston D (eds) Neoliberalism: a critical reader. Pluto Press, London, pp 9-19

Duménil G, Lévy D (2011) The crisis of neoliberalism. Harvard University Press, Cambridge

Eagleton-Pierce M (2016) The handbook of neoliberalism. In: Springer S, Birch K, MacLeavy J (eds) Historicizing the neoliberal spirit of capitalism. Routledge, Taylor \& Francis Group, New York, pp. 17-26

England K, Ward K (2007) Conclusion: reflections on neoliberalizations. In: Ward K, England K (eds) Neoliberalization: states, networks, peoples. Blackwell Publishing, Oxford, pp 248-262

England K, Ward K (2016) Theorizing neoliberalization. In: Springer S, Birch K, MacLeavy J (eds) The handbook of neoliberalism. Routledge, Taylor \& Francis Group, New York, pp 50-60

Eriksen TH, Laidlaw J, Mair J, Martin K, Venkatesan S (2015) The concept of neoliberalism has become an obstacle to the anthropological understanding of the twenty-first century. J R Anthropol Inst 21(4):911-923. https://doi.org/10.1111/1467-9655.12294

Fontana A, Bertani M (2003) Situating the lectures: Alessandro Fontana and Mauro Bertani. In: Ewald F, Fontana A, Davidson AI (eds) Society must be defended: Lectures at the Collège de France, 1975-1976. Picador, New York, pp 273-294

Foucault M (1976) Part five: right of death and power over life (Hurley R, Trans.). In: Foucault M (ed) The will to knowledge: the history of sexuality, vol 1. Penguin Books, pp 133-160

Foucault M (1994a) Interview with Foucault (1984). The ethics of the concern of the self as a practice of freedom. In: Rabinow P, Rose N (eds) The essential Foucault: selections from the essential works of Foucault, 1954-1984. The New Press, New York, pp 25-42 
Foucault M (1994b) Technologies of the self. In: Rabinow P, Rose N (eds) The essential Foucault: selections from the essential works of Foucault, 1954-1984. The New Press, New York, pp 145-169

Foucault M (1994c) The subject and power. In: Rabinow P, Rose N (eds) The essential Foucault: selections from the essential works of Foucault, 1954-1984. The New Press, New York, pp 126-144

Foucault M (1994d) Truth and power. In: Rabinow P, Rose N (eds) The essential Foucault: selections from the essential works of Foucault, 1954-1984. The New Press, New York, pp 300-318

Foucault M (2003) Eleven: 17 March 1976 (Macey D, Trans.). In: Ewald F, Fontana A, Davidson AI (eds) Society must be defended: lectures at the Collège de France, 1975-1976. Picador, New York, pp 239-263

Foucault M (2007a) Eight: 1 March 1978. (Burchell G, Trans.). In: Senellart M, Ewald F, Fontana A, Davidson AI (eds) Security, territory, population: lectures at the Collège de France, 1977-1978. Picador/Palgrave MacMillan, New York, pp 191-226

Foucault M (2007b) Four: 1 February 1978 (Burchell G, Trans.). In: Senellart M, Ewald F, Fontana A, Davidson AI (eds) Security, territory, population: lectures at the Collège de France, 1977-1978. Picador/Palgrave MacMillan, New York, pp 87-114

Foucault M (2007c) Subjectivity and truth. In: Lotringer S (ed) The politics of truth. Semiotext(e), South Pasadena, pp 147-168

Foucault M (2007d) What is critique? In: Lotringer S (ed) The politics of truth. Semiotext(e), South Pasadena, pp 41-82

Foucault M (2007e) What is enlightenment? In: Lotringer S (ed) The politics of truth. Semiotext(e), South Pasadena, pp 97-120

Foucault M (2008a) One: 10 January 1979. (Burchell G, Trans.). In: Senellart M, Ewald F, Fontana A, Davidson AI (eds) The birth of biopolitics: lectures at the Collège de France, 1978-1979. Picador/ Palgrave MacMillan, New York, pp 1-26

Foucault M (2008b) Two: 17 January 1979. (Burchell G, Trans.). In: Senellart M, Ewald F, Fontana A, Davidson AI (eds) The birth of biopolitics: lectures at the Collège de France, 1978-1979. Picador/ Palgrave MacMillan, New York, pp 27-73

French S, Leyshon A (2010) These F@\#king guys: the terrible waste of a good crisis. Environ Plan A A: $1-18$

Fukuyama F (1989) The end of history. Natl Interest 16:3-18

Gibson-Graham JK (2006) The end of capitalism (as we know it): a feminist critique of political economy. University of Minnesota Press, Minneapolis

Gills BK (2010) Going South: capitalist crisis, systemic crisis, civilisational crisis. Third World Q 31(2):169-184. https://doi.org/10.1080/01436591003711926

Gordon C (1991) Governmental rationality: an introduction. In: Burchell G, Gordon C, Miller P (eds) The Foucault effect: studies in governmentality: with two lectures by and an interview with Michel Foucault. The University of Chicago Press, Chicago, pp 1-52

Hall S (2011) The neo-liberal revolution. Cult Stud 25(6):705-728. https://doi.org/10.1080/09502 386.2011.619886

Hamann TH (2009) Neoliberalism, governmentality, and ethics. Foucault Stud 6:37-59

Hartwich OM (2009) Neoliberalism: the genesis of a political swearword. The Centre for Independent Studies. Occasional Paper 114, 48.

Harvey D (2007) A brief history of neoliberalism. Oxford University Press, Oxford

Hendrikse RP, Sidaway JD (2010) Commentary: neoliberalism 3.0. Environ Plan A 42(9):2037-2042. https://doi.org/10.1068/a43361

Hoare G, Sperber N (2016) An introduction to Antonio Gramsci: his life, thought and legacy. Bloomsbury Academic, London

Horkheimer M (1972) Critical theory. Seabury Press, New York

Ishkanian A, Glasius M (2018) Resisting neoliberalism? Movements against austerity and for democracy in Cairo, Athens and London. Crit Soc Policy 1-20

Jessop B (2013) Putting neoliberalism in its time and place: a response to the debate. Soc Anthropol 21(1):65-74. https://doi.org/10.1111/1469-8676.12003

Karskens M (2012) Hoofdstuk 2: Waarheid. In: Karskens M (ed) Foucault. Uitgeverij Boom, Amsterdam, pp 46-77

Kennet P, Dukelow F (2018) Introduction to themed section: neoliberalism's afterlives: states of neoliberalism, power and resistance in post-crisis societies. Crit Soc Policy 1-8

Kruithof J (2000) 14: Strategie. Het neoliberalisme. Uitgeverij EPO, Berchem, pp 469-522

Larner W (2000) Neoliberalism: policy, ideology, governmentality. Stud Polit Econ 63:5

\section{SN Social Sciences}

A SPRINGER NATURE journal 
Leitner H, Sheppard E, Sziarto K, Maringanti A (2007) Contesting urban futures: decentering neoliberalism. In: Leitner H, Peck J, Sheppard ES (eds) Contesting neoliberalism: urban frontiers. The Guilford Press, London, UK, pp 1-25

Lemke T (2000) Foucault, governmentality and critique. In: Proceedings from rethinking marxism conference

Lemke T (2001) 'The birth of bio-politics': Michel Foucault's lecture at the Collège de France on neoliberal governmentality. Econ Soc 30(2):190-207. https://doi.org/10.1080/03085140120042271

Lent J (2020) Coronavirus spells the end of the neoliberal era: what's next? Open Democracy.

Mason P (2015) PostCapitalism: a guide to our future. Allen Lane, UK

Mayer M, Künkel J (2012) Introduction: neoliberal urbanism and its contestations-crossing theoretical boundaries. In: Mayer M, Künkel J (eds) Neoliberal urbanism and its contestations: crossing theoretical boundaries. Palgrave MacMillan, London, UK, pp 3-26

Mirowski P (2014) Never let a serious crisis go to waste. How neoliberalism survived the financial meltdown. Verso, London

Mirowski P (2014) Shock block doctrine: neoliberalism as thought collective and political program. In: Mirowski P (ed) Never let a serious crisis go to waste: how neoliberalism survived the financial meltdown. Verso, London, pp 27-88

Mirowski P, Plehwe D (2015) The road from Mont Pelerin: the making of the neoliberal thought collective. Harvard University Press, Cambridge

Mouffe C (2018) For a left populism. Verso, London

Mudge SL (2008) What is neo-liberalism. Socio-Econ Rev 6(4):703-731. https://doi.org/10.1093/ser/ mwn016

Nietzsche F (1878a) De genealogie van de moraal. Een strijdschrift. Uitgeverij De Arbeiderspers, Amsterdam/Antwerpen

Nietzsche F (1878b) Eerste verhandeling 'Goed en Kwaad', 'Goed en Slecht.' In: Nietzsche F (ed) De genealogie van de moraal: Een strijdschrift. Uitgeverij De arbeiderspers, Amsterdam, pp 17-47

O’Neill P, Weller S (2016) Chapter 7: Neoliberalism in question. In: Springer S, Birch K, MacLeavy J (eds) Handbook of neoliberalism. Routledge Taylor \& Francis Group, New York, pp 84-92

Odysseos L, Death C, Malmvig H (2016) Interrogating Michel Foucault's counter-conduct: theorising the subjects and practices of resistance in global politics. Glob Soc 30(2):151-156. https://doi. org/10.1080/13600826.2016.1144568

Oosterlynck S, González S (2013) 'Don't waste a crisis': opening up the city yet again for neoliberal experimentation. Int J Urban Reg Res 37(3):1075-1082. https://doi.org/10.1111/1468-2427.12064

Parker C (2016) Reassembling the spatial: place-and-world making as social movement practice in Jordan. Proceedings from Paper Presented as part of the 'Social Movements and Popular Mobilisation in the MENA' seminar series, Middle East Center, London School of Economics.

Peck J, Tickell A (2002) Neoliberalizing space. Antipode 34:380-404

Pinson G, Morel Journel C (2016) The Neoliberal City-theory, evidence, debates. Territ Polit Govern 4(2):137-153. https://doi.org/10.1080/21622671.2016.1166982

Plehwe D (2016) Neoliberal hegemony. The handbook of neoliberalism. Routledge, London, pp 61-72

Plewhe D (2015) Introduction. In: Mirowski P, Plewhe D (eds) The road from Mont Pèlerin: the making of the neoliberal thought collective. Harvard University Press, Cambridge, pp 1-42

Purcell M (2016) Chapter 53: Our new arms. In: Springer S, Birch K, MacLeavy J (eds) The handbook of neoliberalism. Routledge, London

Rehmann J (2016) The unfulfilled promises of the late Foucault and Foucauldian "governmentality studies." In: Zamora D, Behrent MC (eds) Foucault and neoliberalism. Polity Press, Cambridge, UK, pp $134-158$

Rossi U (2017) Cities in global capitalism. Polity Press, Cambridge, UK

Saad-Filho A (2020) From COVID-19 to the end of neoliberalism. Crit Sociol 46(4-5):477-485. https:// doi.org/10.1177/0896920520929966

Saad-Filho A, Johnston D (2005) Introduction. In: Saad-Filho A, Johnston D (eds) Neoliberalism: a critical reader. Pluto Press, London, pp 1-6

Sassen S (2014) Expulsions: brutality and complexity in the global economy. Harvard University Press, Harvard

Senellart M (2007) Course context (Burchell G, Trans.). In: Senellart M, Ewald F, Fontana A, Davidson AI (eds) Security, territory, population: lectures at the Collège de France. 1977-1978. Picador/ Palgrave MacMillan, New York, pp 369-402 
Senellart M, Ewald F, Fontana A, Davidson AI (2007) Michel Foucault: security, territory, population: lectures at the Collège de France 1977-1978. Picador/Palgrave MacMillan, New York

Senellart M, Ewald F, Fontana A, Davidson AI (2008) Michel Foucault: the birth of biopolitics: lectures at the Collège de France 1978-1979. Picador/Palgrave MacMillan, New York

Sites W (2007) Contesting the neoliberal city? Theories of neoliberalism and urban strategies of contention. In: Leitner H, Peck J, Sheppard ES (eds) Contesting neoliberalism: urban frontiers. The Guilford Press, London, UK, pp 116-138

Slobodian Q (2018) Globalists: the end of empire and the birth of neoliberalism. Harvard University Press, Cambridge

Springer S (2012) Neoliberalism as discourse: between Foucauldian political economy and Marxian poststructuralism. Crit Discourse Stud 9(2):133-147. https://doi.org/10.1080/17405904.2012.656375

Springer S, Birch K, MacLeavy J (2016) Introduction: an introduction to neoliberalism. In: Springer S, Birch K, MacLeavy J (eds) The handbook of neoliberalism. Routledge Taylor \& Francis Group, New York, pp 1-14

Streeck W (2014) How will capitalism end. New Left Rev 87:35-64

Streeck W (2017) How will capitalism end? Verso, London

Thorsen DE (2010) The neoliberal challenge-what is neoliberalism. Contemp Read Law Soc Just 2(2): $188-214$

Uitermark J, Nicholls W, Loopmans M (2012) Cities and social movements: theorizing beyond the right to the city. Environ Plann A 44(11):2546-2554. https://doi.org/10.1068/a44301

Vargas-Gómez D (2020) COVID-19: neoliberalism is not going down without a fight. Open Democracy.

Venugopal R (2015) Neoliberalism as concept. Econ Soc 44(2):165-187. https://doi.org/10.1080/03085 147.2015.1013356

Wacquant L (2012) Three steps to a historical anthropology of actually existing neoliberalism. Soc Anthropol 20(1):66-79. https://doi.org/10.1111/j.1469-8676.2011.00189.x

Wallerstein I (2004) Historical origins of world-systems analysis: from social science disciplines to historical social sciences. In: Wallerstein I (ed) World-systems analysis: an introduction. Duke University Press, London, pp 1-22

Wallerstein I, Collins R, Mann M, Derluguian G, Calhoun C (2013) Does capitalism have a future? Oxford University Press, New York

Ward K, England K (2007) 1: Introduction: reading neoliberalization. In: Ward K, England K (eds) Neoliberalizations: states, networks, peoples. Blackwell Publishing, Malden, pp 1-22

Zamora D, Behrent MC (2016) Foucault and neoliberalism. Polity Press, Cambridge, UK

Zemni S (2017) The Tunisian revolution: neoliberalism, urban contentious politics and the right to the city. Int J Urban Reg Res 41(1):70-83. https://doi.org/10.1111/1468-2427.12384 